\title{
Fra folkefodbold til fodbold for folket
}

\section{- Fodboldspillets udvikling i England ca. 1314-1914}

\author{
af Claus Nielsen
}

I 1314 udstedte borgmesteren i London, Nicholos Fardon, en „Proklamation for opretholdelse af freden". Heri blev det forbudt for byens indbyggere at spille fodbold. Det hedder bl.a. i proklamationen: „, Og da der er meget oprør i byen (London) p.g.a. visse tumulter, der er opstået p.g.a. sparkning af store fod-bolde på offentlige steder, hvorfra megen ondskab måske opstår hvilket Gud forbyde - beordrer og forbyder vi på Kongens vegne, med henvisning til fangenskabets smerte, at et sådan spil ikke fremover skal praktiseres i byen ..."

Dette forbud er den ældste kilde, der med sikkerhed viser eksistensen afet fodboldspil. Fodboldspillets historie strækker sig altså ihvertfald fra 1314 og frem til vore dages næsten afgudsdyrkelse af fodboldstjernerne.

I det følgende vil jeg beskrive denne udvikling. Fodboldspillets historie er en lang historie med mange facetter, sammenhænge og funktioner, som det naturligvis ikke alt sammen er muligt at få med her. Jeg har derfor valgt at lade denne fremstilling af fodboldspillets historie være et rids med tyngdepunkter på middelalderens fodbold, fodboldspillets regelsætning i 1800tallet og masseudbredelsen af det regelsatte fodboldspil med etableringen af de engelske fodboldklubber vi kender $i$ dag. Fremstillingen slutter 1914, hvor det fodboldspil, vi i dag kender, er etableret.

\section{Fodboldspillets oprindelse}

At man kan datere fodboldspillet tilbage til i hvert fald 1314, betyder naturligvis ikke at fodboldspillet 'fødtes' i 1314. Fodboldspillet er uden tvivl meget ældre. Men hvor længe, hvor og hvordan, der er blevet spillet fodbold, fortaber sig dels i usikre kilder og dels i manglen på kilder.

Flere forskere har forsøgt sig med bud på fodboldspillets oprindelse og udbredelse. Man har søgt at finde et bestemt oprindelsessted. Det er f.eks. blevet undersøgt om vikingerne eller andre rejsende skulle have bragt spillet med sig til England. Der findes en lille legende, der går ud på, at spillet oprindeligt hed "The Danes Head" - „Danskerens hoved" - fordi den første 
fodbold skulle være det afhuggede hoved af en dansk viking, som man engang omkring år 1000 sparkede igennem gaden i en engelsk landsby.

Det er dog, efter min mening, en blindvej at søge fodboldspillets oprindelse på et bestemt tidsligt og geografisk sted. Det mest sandsynlige er, at en form for fodboldspil er startet på forskellige steder og til forskellige tider uafhængig af hinanden. Jeg tror, at boldspilleri på en måde ligger lige for - er 'naturligt'. De bolde, man i fodboldspillets første hundreder af år spillede med, var oppustede svineblærer. Jeg tror, at det har ligget 'naturligt' for folk, at puste blæren fra et slagtet dyr op - for så derefter at lege og spille med den. Leg, spil, og festeri var jo noget, der før i tiden var tæt forbundet med hjemtagning af større mængder føde (f.eks. høst eller fangning af hvaler o.l.).

Fodbold-lignende spil kan findes mange steder på kloden langt tilbage i tiden. F.eks. spillede man et fodbold-lignende spil i Kina under Tangdynastiet (618-907), og da Hans Egede var på Grønland 1721-36, spillede eskimoerne en slags fodboldspil.

Men uanset boldspilleri $i$ forskellige kulturer til forskellige tider er det $\mathbf{i}$ England, at den boldspil-udvikling, der førte frem mod vore dages fodboldspil, er foregået.

\section{Fodboldforbud i middelalderen}

I 1314 er vi altså sikre på, at man spillede fodbold i England. At kilden er et forbud, viser at spillet var ret populært. Dets udbredelse generede autoriteterne så meget, at de så sig nødsaget til at udstede et forbud. Dette i et samfund, der ellers ikke var præget af de store lovgivningskomplekser. At spillet var populært ses desuden af, at folk åbenbart så stort på forbudet. I 1331 udstedte Edward III endnu et forbud. Folk var åbenbart ligeglade - de ville spille fodbold. Igen i 1365 så Edward III sig nødsaget til at udstede et forbud. Og sådan fortsætter det. Jævnligt op igennem 13-14-15-1600-tallene udstedes der forbud imod fodboldspilleri.

Forbudene havde to begrundelser. For det første var spillet årsag til larm, tumulter, kaos o.l. Når spillet bølgede igennem gaderne - i f.eks. det middelalderlige London - med store fodbolde, var både personer og bygninger $\mathrm{i}$ fare for at lide overlast. For det andet skulle forbudene modvirke, at folk spillede fodbold i stedet for at øve sig med bue og pil, hvad der var af stor vigtighed for landets forsvar og for de engelske kongers krige mod især Frankrig. I 1300-tallet og i første del af 1400-tallet havde langbueskytterne stor succes mod tunge og klodsede ridderhære. Dette gav englænderne en overlegenhed over for franskmændene i hundredeårskrigen (1337-1453) og førte til sejre i vigtige slag. I løbet af 1400-tallet begyndte kanonen og 
håndskydevåbenet at blive dominerende og trænge langbuen ud. Hermed forsvandt det ene af fodboldforbudenes begrundelser. Dette mindskede dog ikke forbudene og fordømmelserne mod fodboldspilleriet. Herefter blev det henvisningerne til tumulter og uorden, der blev dominerende i fordømmelserne.

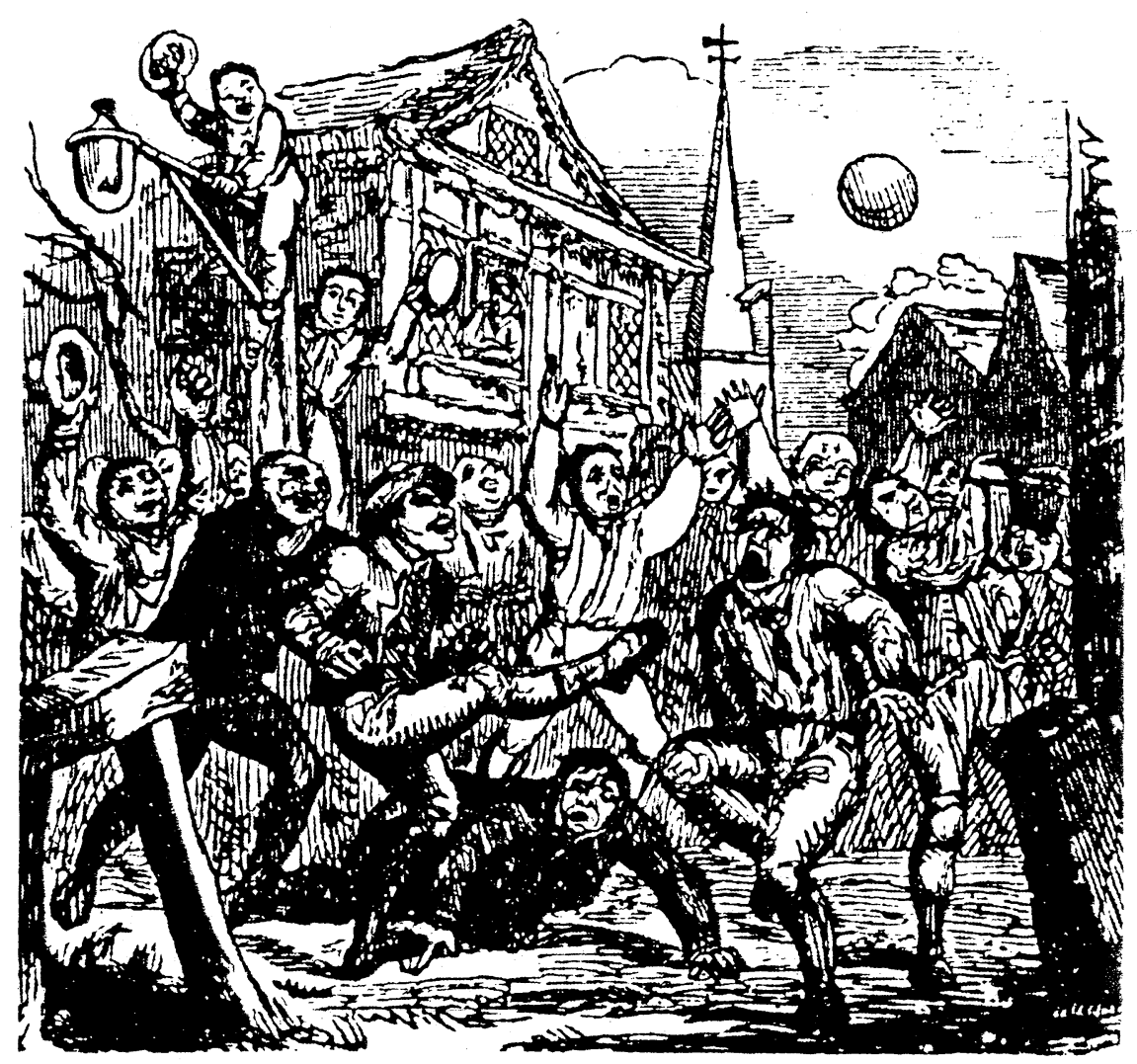

Folkefodbold $i$ byernes gader var et voldsomt spil, der gav anledning til uorden og mange tumulter. Billedet her er fra begyndelsen af 1800-tallet. 


\section{Middelalderens fodbold}

Hvorledes så dette fodboldspil, som autoriteterne havde så svært ved at tøjle, da ud? Som nævnt må vi gå ud fra, at spillet var meget populært. Det var nærmest udelukkende de nederste i samfundet, der spillede det, og det var således i opposition til elitens legemskultur (ridderlige idrætter). Det spil, man spillede frem til regelsætningen midt i 1800-tallet, - folkefodbold kan man kalde det - var et regelfattigt og efter vore normer voldsomt spil. Skader som rifter, slag og brækkede lemmer var ikke ualmindelige. Spillet foregik mellem to grupper af varierende antal. Hele landsbyer kunne deltage. Man spillede ofte mellem to landsbyer eller mellem to grupper fra den samme landsby. Spilleområdet var byens gader og områderne mellem to landsbyer. Man spillede således på markerne, gennem bakker og dale, vandløb, krat, eng-arealer o.l. Efter alt at dømme var kirkegårdspladserne også et yndet sted at spille fodbold i middelalderen. Gentagne forbud mod fodbold og andet spilleri og leg på kirkegårdspladserne vidner om dette. 'Målene' var f.eks. de to landsbyer, et hus, en port eller lign. i hver ende af landsbyen eller i de to landsbyer. Det gjaldt så om at drive bolden ind i modstanderens "mål'. Den, der først gjorde det, havde vundet. Dette varede som regel mange timer, hvor kampen bølgede frem og tilbage gennem gaderne og over markerne. Bolden var en oppustet svineblære, der i nogle tilfælde var indhyllet i læder. Den mere præcise spillemåde varierede fra egn til egn.

Som nævnt var spillet voldsomt, i hvert fald hvis vi ser det ud fra vores målestok. I 1326 gav Pave John XXII en dispensation fra hans sæde i Avignon til kanniken William de Spalding:

„Til William de Spalding, kannik i Scoldham. Under boldspillet, da han sparkede til bolden, rendte en ven imod ham, der også kaldes William, og sårede sig selv på en kniv siddende $\mathrm{i}$ skeden, båret af kanniken, så alvorligt at han døde i løbet af seks dage. Dispensation er givet, da der ikke kan lægges nogen skyld på William de Spalding, der sørgede dybt over sin vens død og frygtende, hvad hans venner ville sige, har appelleret til Paven."

Som denne - og lignende beretninger - viser, førte fodboldspillet ind imellem til dødsfald. Også brækkede ben var blandt de skader, spillerne ikke sjældent kunne komme ud for.

De fleste af kilderne, der beretter om fodbold i middelalderen, er forbud og beretninger, hvor spilleriet har været årsag til ulykker. Kun sjældent beskrives selve spillet nærmere. En af de første kilder, der beskriver fodboldspillet $i$ en lidt større helhed, er fra slutningen af 1400-tallet. Kilden er en samling af 
mirakler udført af kong Henry VI fra 1481 til 1500. Hovedpersonen i kilden er en William Bertram, der havde været syg og længe havde lidt efter at være blevet sparket ned under en fodboldkamp. Han blev pludselig helbredt efter at have set kong Henry $i$ en drøm. 'Mirakelbogen' fortæller om Williams uheld:

„Spillet som de mødtes til for fælles rekreation kaldes af nogle fod-bold spillet. Det er et spil hvori unge mænd driver en stor bold frem ikke ved at kaste den op i luften men ved at slå og rulle den langs jorden og ikke med deres hænder men med deres fødder. Et spil, siger jeg, afskyeligt nok og, i det mindste i mine øjne, mere almindeligt, uværdigt og værdiløst end noget andet spil, det slutter sjældent uden tab, ulykker eller skade på spillerne selv. Hvad så? Grænserne var blevet markeret og spillet startet; og, mens de kæmpede mandigt/tappert, sparkede i forskellige retninger, og vores helt havde kastet sig ind $\mathrm{i}$ midten af kampen, kom en af hans kammerater, hvis navn jeg ikke kender, op imod ham forfra og sparkede ham ved et uheld, da han kiksede sit spark på bolden."

Som det ses af denne beretning, er der varianter af det middelalderlige folkefodboldspil, hvor man markerede spillepladsen, og hvor man især (kun?) brugte benene til at drive bolden frem. Selv om spillet var regelfattigt, indeholdt det altså visse regler. Det har været regler, der blev givet videre mundtligt og pr. praksis.

Som langt de fleste af beretningerne om fodbold til et godt stykke ind $i$ 1800-tallet, er kilden fordømmende over for spillet. Spillet er afskyeligt, uværdigt og værdiløst, mener kildens forfatter.

Sådan nævnes fodbold ustandseligt $i$ kilderne, samtidig med at det voldsomme nærmest voldelige betones. Samuel Butler - rektor på Shrewsbury Public School 1798-1836 - mente, at spillet „kun passede til slagterdrenge “ og, ,,at det passede mere for bondedrenge og arbejdere end for unge gentlemen."

I denne udtalelse siges direkte, hvad der ligger implicit i de fleste andre kilder om fodbold tilbage til 1314: Fodbold var et underklassespil. Det var bønder og (senere) arbejdere, der spillede det. Og det var ikke noget for overklassens gentlemen-drenge. Hermed får vi også forklaringen på den fordømmende tone i kilderne. Det var folk uden for fodboldspillet og den kultur, hvori det eksisterede, der beskrev det. For de var jo helt enkelt (stort set) de eneste, der skrev. Desværre har vi derfor ingen beretninger, der fortæller om, hvordan de implicerede selv oplevede spillet. Oplevede de det også frygtelig voldeligt? Naturligvis gjorde de ikke det. Så ville de ikke have 
spillet spillet. Og det ville da slet ikke have været så populært, som det helt klart var.

Fodbold var en del af den kultur, hvori det med så stor iver udøvedes. Denne kultur var, hvad man med et lidt upræcist begreb kalder, folkekulturen. Denne folkekultur bestod bl.a. af en lang række traditioner, der blev udøvet på diverse fest- og helligdage. En lang række spil og lege var led i disse traditioner, - ofte også fodbold. F.eks. plejede en fodboldkamp at blive spillet i Kirkhams gader (i Lancashire) juledag. Så snart middagsmaden var overstået, blev alle udvendige skodder lukket, og kampen begyndte. Også i påsken var det normalt at spille fodbold. I denne højtid blev fodbold og andre spil og lege sædvanligvis spillet på kirkegårdspladserne og i gaderne.

Det var dog på hvidetirsdag - tirsdag efter fastelavn - at det var mest almindeligt at spille fodbold. I en lang række regioner over hele England var fastelavns-fodboldspillet igennem århundreder en fast tradition. Hvidetirsdag - også kaldet pandekagedag - var efter juledag den mest populære festog helligdag. Dagen var fyldt med mange nydelsesmæssige traditioner bl.a. pandekagespisning. Andre ingredienser i dagen var bl.a. at rulle et brændende hjul igennem landsbyerne og ægge-rulning.

Det er interessant at lægge mærke til de runde former, der går igen. Det er symboler, der kan spores langt tilbage som frugtbarhedssymboler. Mon ikke det er solen, man finder i bolden, som der - selv i kirkerne - blev spillet cermonielle spil med? F.eks. spillede kannik og domprovst indtil ind $i$ 1500-tallet visse steder bold den 1. maj i midtskibet før aftensang. Man dansede og puffede bolden, mens man sang. Solen forbindes ofte med noget hoppende og dansende og kan derfor let forbindes med bolde, der fungerer som symbol på solen. Der var da også visse steder, hvor bolden skulle dyppes i en flod eller andet vand for at symbolisere foreningen af sol og regn, der jo var vigtig for den afgrøde, man netop havde sået eller skulle til at så. Og dermed af afgørende betydning for selve livsgrundlaget. At tolke bolden som et solsymbol får forstærket kraft i og med, at det netop var i det tidlige forår overgangen mellem vinter og sommer - at fodboldspillet var mest traditionsfast.

Der er altså stor sandsynlighed for, at spillet oprindeligt havde et religiøst (hedensk) indhold. Dette er så løbende gået tabt, mens traditionen og spillet fortsat levede/lever. Det er ikke ualmindeligt, at oprindeligt religiøse traditioner er blevet tømt for betydning, for så at fortsætte som spil og leg.

Fra at have en religiøs funktion har spillet fået en funktion som del af folkekulturen. F.eks. har de samme to grupper i landsbyen eller de samme to landsbyer år efter år mødtes hvidetirsdag til fodboldkamp. Spillet har fungeret som en slags rituel kamp mellem de to grupper, og er indgået som en del af deres kulturhistorie med aner langt tilbage i tiden. Det har været en 
kamp om status og prestige i lokalsamfundet. F.eks. plejede hvidetirsdagsfodbold i Workington (i Cumberland) at være en lang, ihærdig og voldsom kamp mellem byens minearbejdere og sømænd. Målet for minearbejderne var at få bolden over porten til „Curwen's Hall“ i den øvre del af byen. Sømændene skulle få bolden ned til spillet på havnen. Der var mange spillere og tusinder af tilskuere, og spillet bølgede af sted uanset hække, hegn og andre forhindringer. Hvor langt tilbage denne tradition rækker er usikkert.

At spille fodbold har uden tvivl også været en slags modkulturel aktivitet over for magthaverne. Trods de tidligere nævnte forbud, blev man ved med at spille fodbold. Det er muligt, at man i det daglige blev udbyttet, var undertrykt og underlagt autoriteter, man ingen indflydelse havde på. Fodboldspillet skulle de åbenbart ikke bestemme over.

\section{Fodbold og folkemodstand i 1700-tallet}

I løbet af 1700-tallets England begyndte de omvæltninger at tage fart, der endte $\mathrm{i}$ den industrielle revolution og de meget store samfundsmæssige forandringer, dette indebar. Blandt de vigtigste omvæltninger var en begyndende opbrydning af folkekulturen. Fodboldspillet fik hermed en ny funktion. Der er flere eksempler på, at spillet indgik i de nederste klassers modstand mod den nye udbud-og-efterspørgsels-økonomi og enclosurebevægelsen (indhegning og fratagelse af bøndernes fælled). F.eks. samledes i 1740 en menneskemasse for at spille fodbold. Da man var samlet, gik man hen og rev en nærliggende mølle ned. Denne mølle havde forbrudt sig mod de traditionelle markedsregler. I modstanden mod enclosure er der flere eksempler på, at de folk, de havde fået frataget deres fælled, rev indhegningen ned og spillede fodbold der. Foruden det rent oprørske, skal det, at man spillede fodbold på fælleden, sikkert også ses som en symbolsk gen-indtagelse af fælleden. Fodboldspillet kom således til at indgå i de nederste samfundsgruppers kamp imod de omvæltninger, der bl.a. betød en ødelæggelse af deres traditionelle samfund og kultur.

\section{Folkefodbold under pres først i 1800-tallet}

I 1801 skrev Joseph Strutt i sit store klassiske værk ,,The Sport and Pasttimes of the People of England“: „,Det (fodboldspillet) var førhen meget populært blandt den jævne befolkning, det ser dog ud til, at det inden for de senere år er kommet i miskredit og praktiseres nu kun sjældent."

Det ser altså ud til, at fodboldspillet var ved at uddø omkring 1800. 
Folkekulturen var i vid udstrækning brudt op, og de (bønder og landarbejdere), der spillede fodbold, var for manges vedkommende tvunget ind $i$ de hastigt voksende storbyer som arbejdere $\mathrm{i}$ fabrikkerne og den hurtigt ekspanderende industri.

Dette er dog ikke helt rigtigt. Mange steder forsøgte de nye arbejdere at overføre de folkekulturelle traditioner til de nye industribyer. Dette blev med kraftige midler søgt forhindret. Der foregik en bekæmpelse af folkekulturen og dens indhold, idet der heri lå en moral, nogle værdier og normer, der var (er) uforenelige med den industrielle, urbane og kapitalistiske kultur.

Et fint eksempel på folkekulturens modstand stammer fra Derby. Her havde hvidetirsdags-fodbold en lang og stærk tradition, som der gennem tiden var gjort mange (mislykkede) forsøg på at undertrykke. Frem mod midten af 1800-tallet besluttede myndighederne i Derby at sætte en endelig stopper for spillet. I 1845 blev en begæring afleveret til borgmesteren, hvori spillet blev fordømt i stærke vendinger. Bl.a. blev spillerne beskrevet som lovløst pak! Foruden de sædvanlige klager om tumulter o.s.v. klagede man over, at forretningerne måtte holde lukket „til tab for de flittige“, når fodboldspillet foregik. Endnu engang blev spillet erklæret illegalt, og der blev truet med anholdelser og bøder. Da hvidetirsdag oprandt, var der alligevel en stor flok, der gav bolden op og spillede fodbold. Af disse blev en del anholdt og idømt bøder.

Áret efter - 1846 - var der lagt op til konfrontation. Ordensmagten havde forberedt sig godt på en forestående konflikt, - flere hundrede 'respektable indbyggere' var taget i ed som specialbetjente. Desuden var der ankommet kavaleri-tropper til byen. Da bolden var givet op, angreb og fornærmede spillerne specialbetjentene. Tropperne blev sat ind, forfulgte og splittede spillerne, og man formåede at hindre, at der blev spllet fodbold. I 1847 var der atter konfrontation. Her splittede man folk, allerede mens de var ved at samle sig. Altså før bolden blev givet op. I 1848 og 1849 var tropper atter tilkaldt for at opretholde freden. Her blev der dog ikke gjort forsøg på at spille fodbold. Så sent som 1853 blev der gjort forberedelser til at imødegå en evt. gentagelse af fodboldspillet.

Derby-eksemplet er langtfra det eneste eksempel på modstand mod forsøg på at undertrykke fodboldspillet. Over midten af 1800-tallet lykkedes det efterhånden for autoriteterne at undertrykke store dele af folkekulturen og herunder folkefodbold-spillet. Det lykkedes bl.a., fordi man havde langt bedre midler end tidligere. BI.a. var politikorpset $\mathrm{i}$ begyndelsen af århundredet blevet dannet. Dette politikorps var meget aktivt og patruljerede meget $i$ gaderne-bl.a. i arbejderkvartererne. 


\section{Fodbold på Public Schools ca. 1800-1850}

En gang i løbet af 16-1700-tallet var folkefodboldspillet blevet optaget på de højere læreanstalter, universiteter og Public Schools. Public Schools var kostskoler for overklassens drenge. Disse drenge havde taget de forskellige lokale varianter af spillet til sig og spillede det lidenskabeligt på deres skoler. Spillet fungerede i det hierakiske magtforhold mellem eleverne. De svage og yngre elever måtte finde sig i at blive sparket ned, herset med o.l. af de ældre og stærke elever, der var de dominerende i spillet.

Eleverne havde en udstrakt grad af selvstændighed på skolerne. Lærerne havde lavere social status end eleverne, der derfor ikke ville finde sig $i$ at blive hersket alt for meget over. Dette resulterede i magtkampe på skolerne. Fra ca. 1790 til ca. 1830 udbrød der ind imellem regulære elevoptøjer. Nogle var så voldsomme, at der måtte indsættes militær med trukne bajonetter for at stoppe dem.

Omkring 1830 begyndte man at indføre reformer på skolerne. Hovedkravene var større autoritet til lærerne og skoleledelserne og større vægt på boglig dannelse og udviklingen af den borgerlige karakter.

I disse reformer indgik fodboldspillet. Overklassen var stadig fjendtlig over for spillet, men man fandt ud af at bruge spillet som led i reformerne. Efterhånden blev de regler, drengene havde spillet efter, derfor ændret. Fodbold skulle i højere grad udtrykke de borgerlige værdier og normer (fair-play f.eks.), hvorfor det blev nødvendigt med strammere regler. I den forbindelse opstod der uenighed om reglerne, og man så sig nødsaget til at blive enige om nogle regler, og at skrive dem ned. De først nedskrevne regler menes at være fra Rugby School i 1846. I 1849 kom regler på papir i Eton. Det var ikke hele regelsæt, man skrev ned, men kun emner man var uenige om. Blandt disse emner var, hvor stor grad af fysisk magt, det var tilladt at bruge.

\section{Fodboldspillets regelsætning}

Fra over midten af 1800-tallet begyndte tidligere Public School-elever at danne småklubber rundt om i landet. I disse klubber spillede man, som man havde gjort på de skoler, man kom fra. Dette fremkaldte naturligvis problemer, når man skulle møde hinanden. Hvilke regler skulle man spille efter?

Det blev derfor påtrængende med et fælles regelsæt, der gjaldt for hele England. Der afholdtes i 1863 i London en række stormfulde møder med dette sigte. Særlig stor forskel var der mellem Rugby- og Eton-varianterne. Rugby-tilhængerne gik ind for, at man måtte sparke hinanden over skinnebenet (hacking), at man måtte tage bolden med hænderne, og at der var mål når 


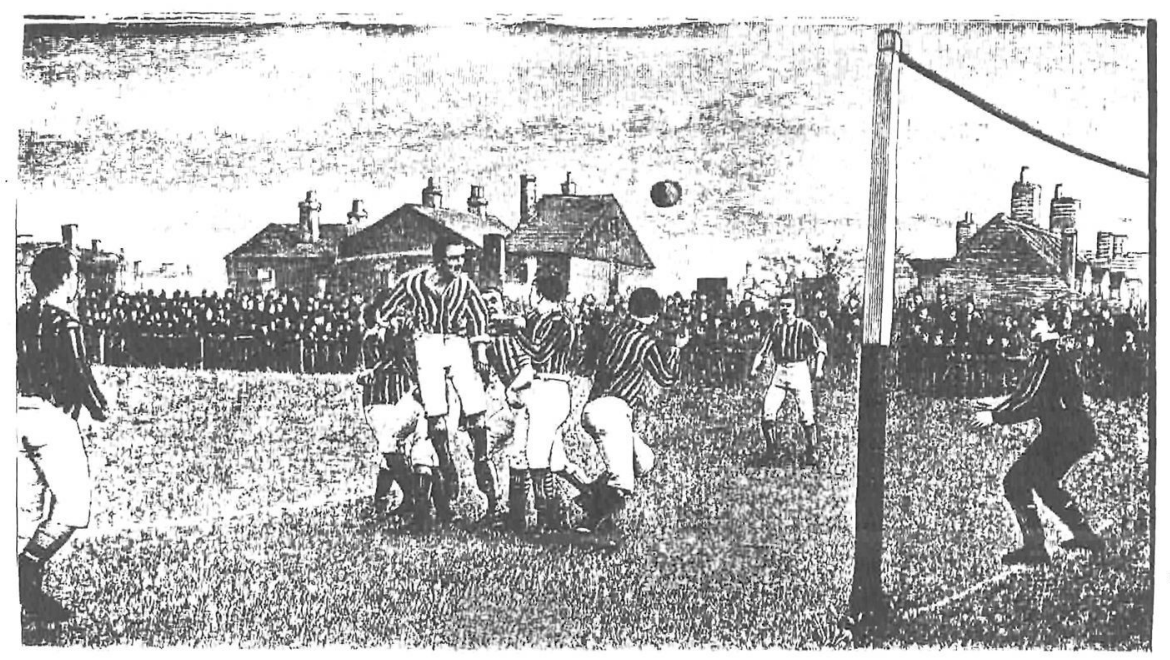

Billede fra en fodboldkamp i 1888 - året hvor ligaen blev grundlagt: Tilskuerne må klumpe sig op ad et hegn langs sidelinien. Man begyndte dog hurtigt - fra 1880'erne - at bygge tribuner. Læg mærke til overlæggeren, der blot er en snor trukket mellem de to stolper. Og der er ikke net i målet.

bolden blev sparket over målstængerne. Eton-tilhængerne mente, at man ikke måtte sparke hinanden, at det var forbudt at fange, bære, kaste eller slå til bolden med hænderne, og endelig - at der var mål, når bolden blev sparket mellem målstængerne.

Disse uenigheder var for store til at kunne overvindes. En række klubber trådte derfor ikke ind i Det Engelske Fodboldforbund (FA), hvis dannelse blev udgangen af møderne. 'Outsider-klubberne' dannede i 1871 Rugby Fodboldunionen.

I begyndelsen bestod FA hovedsageligt af sydlige klubber. I 1868 var der 30 stk. Efterhånden sluttede flere sig til, således at der fra 1882 fandtes et fælles nationalt regelsæt for fodboldspillet (soccer): I 1871 startede FA-cup'en (pokalturneringen) og i 1888 startede man ligaen op. I 1885 var brugen af professionelle spillere blevet legaliseret. 


\section{Udbredelsen af det regelsatte fodboldspil}

Det regelsatte fodboldspil blev lynhurtigt populært og bredte sig med eksplosionsagtig kraft. I sidste fjerdedel af 1800-tallet udbredtes spillet fra middel- og overklassen til arbejderklassen, der i løbet af århundredet med den kraftige industrialisering havde vokset sig stor og dominerende.

Især folk fra middelklassen gjorde kraftige forsøg på at 'civilisere' arbejderklassen, - d.v.s. indgyde arbejderne borgerlige normer og værdier (f.eks. sparsommelighed, flid, behovsudsættelse, afholdenhed o.I.) Eksempelvis foregik der i forbindelse med forskellige kirkesamfund et stort arbejde for at få arbejderne til at holde sig væk fra drikkeri, spilleri o.l. og i stedet give sig til noget 'nyttigt'. Arbejdernes fritid var blevet problematisk i og med, at arbejdstiden over midten af 1800-tallet var blevet nedsat. Bl.a. indførtes ca. 1850-75 'engelsk weekend', hvilket betød, at den halve lørdag var fri.

I denne 'middelklasse-missionering' indgik fodboldspillet. Mange dominerende fra middelklassen (f.eks. præsterne) var tidligere Public School-elever, der kendte og elskede spillet. Nogle af de aktiviteter arbejderne blev tilbudt var derfor bl.a. fodbold. Det var en aktivitet, der opfyldte behovet for fysisk aktivitet og frisk luft. Mange af de engelske klubber, vi i dag kender, er dannet ud fra sådanne aktiviteter. Det gælder f.eks. de engelske mestre fra1985 - Everton (fra Liverpool).

Fra en nyopført metodistkirke - St. Domingo - med tilhørende skole udsprang i 1878 St. Domingo Club. I begyndelsen spillede man fodbold $i$ et hjørne af en nærliggende park (Stanley Park), hvor man hver spille- og træningsdag opsatte mål og udmålte banen. Efterhånden som der dukkede flere spillere op uden tilknytning til kirken, fandt man det nødvendigt at skifte navn. Fra november 1879 hed klubben Everton. Det var en ret almindelig udvikling, at klubber dannedes ud fra eller omkring kirker eller kirkesamfund for så at vokse væk fra dette udgangspunkt. F.eks. skiftede klubben Christ Church i august 1877 navn til Bolton Wanderers F.C., der senere fik stor succes. Dette skete, efter at præsten havde gjort indsigelser imod, at klubben holdt møde i kirkens skole, når han ikke var til stede. Hovedgrunden til dette var sikkert, at man i fodboldklubben ikke længere bekymrede sig særlig meget om det kirkelige. Nu var det kun fodbolden, der havde interesse. I sæsonen 1883-84 flyttede Everton fra Stanley Park til en privat grund, som det var muligt at sætte hegn omkring (Goodison Park). Derved var det muligt at kræve entré af det stadig stigende antal tilskuere. I sæsonen 1885-86 ansatte Everton sin første professionelle spiller. Fra 1883 til 1885 fik man installeret net i målene. Hurtigt gled klubben over fra at have eksisteret som ren fornøjelse til at være strengt professionel.

Evertons udvikling er typisk for mange af de senere kendte klubber. Det er 
blevet anslået at mindst $25 \%$ af fodboldklubberne i deres første fase havde forbindelse med religiøse organisationer. Andre 'kirkedannede' klubber er f.eks. Aston Villa, Birmingham City, Burnley, Wolverhampton, Fullham og Barnsley.

Klubber blev dannet på en række andre måder f.eks. ud fra fabrikker, pubs og boligkvarterer. F.eks. er West Ham dannet ud fra skibsbyggerfirmaet The Thames Ironwork i West Ham (London). Klubben var i begyndelsen en slags velfærdsklub ledet og dannet af fabrikkens ledelse. Andre klubber blev dannet autonomt af spillerne selv. Således Arsenal, der blev dannet af arbejdere på Woolwich Arsenal våbenfabrik, hvor den kongelige flådes kanoner blev lavet. Historien fortæller, at arbejderne i 1886 skrabte 10 shillings sammen, købte en bold, dannede deres egen klub og begyndte at spille fodbold.

I det hele taget gik det i de sidste par årtier af 1800-tallet gevaldigt stærkt med fodboldspillets udvikling. Masser begyndte at spille fodbold. For mange arbejdere blev det en mulighed for at slippe ud af fabrikshallernes larm, sod og monotomi. Interessen for at se på fodboldkampene blev også lynhurtigt enorm. Den første cup-finale i 1872 blev ovenæret af 2000 tilskuere. I 1888-finalen så 17.000 på. Fra 1895 til 1915 afholdtes finalen i Crystal Palace i London (Wembley blev bygget i 1923). Her steg tilskuertallet kraftigt: 66.000 (1897), 69.000 (1900), 110.000 (1901), 120.000 (1913).

Omkring århundrede-skiftet havde det regelsatte fodboldspil udviklet sig til et arbejderklasse-spil. Den langt overvejende del af både spillere og tilskuere kom fra arbejderklassen. Over- og middelklassen ville ikke være med til professionaliseringen af spillet. At få penge for en fritidsfornøjelse betragtedes som umoralskt og uværdigt. Fodboldspillet, der udspillede sig hver lørdag eftermiddag, når fabriksportene var lukket, blev $\mathrm{i}$ høj grad det, der var (er) med til at karakterisere den engelske arbejderkultur.

Med 1. verdenskrig (1914-18) kom der en lille parentes i fodboldspillets historie. Turneringen stoppede i 1915, da spillere og de mandlige tilskuere burde være ved fronten. I Nordfrankrigs mudder og skyttegrave blev spillet dog langt fra glemt. Den 1. bataljon af det 18. London-regiment førte i 1915 et angreb ved Loos ledet af mænd, der sparkede en fodbold foran sig. Ved Somme i 1916 udsatte kaptajn W. P. Nerville en pris til den første deling, der spillede og sparkede en fodbold frem til den tyske frontlinie.

Det spil, der spilledes i 1914, er både hvad indhold og omgivelser angår identisk med det spil, vi kender i dag. Udviklingen frem mod det moderne fodboldspil kan således siges at være tilendebragt i 1914. Det var det spil, der omkring århundredeskiftet blev eksporteret fra England til de fleste europæiske lande og Sydamerika. 


\section{Udvalgt litteratur}

E. K. Chambers ,,The Medieval Stage“" London 1925.

Eric Dunning „The Development of Modern Football“ i Eric Dunning (red.) „The Sociology of Sport" London 1970 pp 133-52.

F. P. Magoun jr. ,,History of Football - from the beginnings to 1871“" Bochum 1938. „Football in Medieval England and in Middle English Literature" i American Historical Review vol. xxxv no. 1 October 1939 pp. 33-45.

M. Marples ,A History of Football“ London 1954.

Tonny Maron ,Association Football and English Society 1863-1915“ Brighton 1980.

Claus Nielsen „,Fra lovbrydere til folkehelte. - Fodboldspillets udvikling i England 1800-1914" Speciale Århus 1984.

A. R. Wright „British Calendar Custums“" vol. I-III London 1936-40. 
